UDC 81

DOI: $10.24045 / f v .2017 .4 .2$

\title{
TOLERANCE/INTOLERANCE: PRAGMATIC APPROACH
}

\author{
A. Simonyan
}

Doctor of Philological Sciences, professor,

ORCID 0000-0001-5837-1988,

e-mail: sim-var@hotmail.com,

Russian-Armenian University,

Yerevan, Armenia

\begin{abstract}
In the paper an attempt is made to show the relationship between tolerance/intolerance and the speech acts used in political communication. Tolerance in political discourse is one of the conditions for the successful communication. A tolerant politician is understood as a person who realizes, accepts and shares responsibility for the process and the result of a communicative situation. Breach of tolerance can completely destroy the reputation of a politician.
\end{abstract}

Keywords: tolerance; intolerance; speech acts; communicative situation, political interview, impact, audience.

Modern linguistics deals with the development of the correlation of formal-structural parameters and their contextual representation. In this connection, a special interest is paid to the manifestation of the theory of speech acts in political communication. The theory of speech acts was proposed by $\mathrm{J}$. Austin and further developed by J. Searle. According to this theory, the smallest unit of human communication is not a phoneme, lexeme or even a sentence, but the performance of certain actions (acts), such as asking a question, ordering, asking, convincing, explaining, proving, promising, refusing, etc. J. Austin divides the speech acts into three groups: a) locutionary, b) illocutionary, c) perlocutionary [5]. J. Searle recognizes only two types of speech acts - illocutionary and perlocutionary, he considers the locutionary act a variant of illocutionary [7].

In his works he tries to show how the locutionary or illocutionary act become perlocutionary, in other words, how the utterance can make or induce the addressee to perform certain actions. J. Searle proposes a set of rules that must be followed in such a transformation.

1. Rule of propositional content (propositional-content rule), when the utterance (proposition) predicts some future action of the speaker.

2. Preparatory rules, when both the speaker and the hearer strive for the action to take place, and the addressor must expect that the action will be carried out.

3. The rule of sincerity (sincerity rule), when the speaker feels obligated to perform this action.

4. Essential rule (essential rule), when the utterance $\mathrm{p}$ is considered to be an obligation to perform the action [7].

Ideal verbal communication means selfinterested, reciprocal interaction which presupposes the fundamental expectation that both sides should communicate truthfully and sincerely. Serious analysis on this problem was carried out by the famous philosopher and linguist Paul Grice. According to Grice's conception, human communication cannot exist without a cooperative principle which involves 4 types of maxims:

I. Maxim of Quantity. Make your contribution as informative as is required. Do not make your contribution more informative than is required.

II. Maxim of Quality. Supermaxim: Try to make your contribution one that is true. Specific maxims: Do not say what you believe to be false. Do not say that for which you lack adequate evidence.

III. Maxim of Relation. Be relevant.

IV. Maxim of Manner. Supermaxim: Be perspicuous. Specific maxims: Avoid obscurity of expression. Avoid ambiguity. Be brief. Be orderly [2].

In general, P. Grice's maxims should be considered as acceptable guidelines for effec- 
tive communication. Abandoning the maxims would suggest refusing to communicate properly altogether. However, violations of maxims are also possible. One could violate the maxims by refusing to give information in court or telling a half-truth and calculating that nobody would find out what had really happened before. Sometimes maxims cannot satisfy all the aspects of living, dynamic speech. It is therefore not surprising that some linguists began to express a certain doubt about the validity of this theory.

Communication is also called a communicative situation, a natural environment in which any dialogue with its verbal and nonverbal representation takes place $[6, p .141]$. "The communicative situation is a fragment of an objectively existing reality with factors (in the broadest sense) of communication and its participants and modifiers (that is, who, what, where, when) [4, p. 125-126]".

The interview is a situation of communication, presented in the form of a dialogue. The interview can also be viewed as a discourse determined by the variety of factors. The cohesion or connectivity of the discourse is determined not only by the syntactic or semantic factors of the surface structure but also by the connectivity of the communicative-pragmatic factors underlying the internal textual structure. Studies in the field of linguistics reveal the interconnection between the lexical-semantic units and their pragmatic representation. In many cases, the semantic description proceeds from the pragmatic description, meanwhile the pragmatic analysis of the proposal is based on the semantic description. There is no semantics without pragmatics - but there is also no pragmatics without semantics [3, p. 347].

In political communication tolerance is of great importance. Tolerance means active and constructive cooperation, participation, solidarity; it is based on the principles of cooperation and a good will. Tolerant communicative behavior is a goal-oriented activity aimed at equality and parity in conducting a dialogue, the participants of which should be aware of the competent use of language material, speech skills related to a certain com- municative situation and the intention of the interlocutors.

A tolerant personality in cooperative communication is understood as a person who realizes, accepts and shares responsibility for the process and the result of a communication situation. Tolerant person actively participates in the conversation and is centered not only on himself and on achieving his goals, but also on the communication partner as the subject of communication.

The manifestation of tolerance and the very degree of the obligation of tolerant behavior in various communicative situations is determined by a large complex of verbal and non-verbal factors. Language in terms of the formation of tolerant communicative interaction is the tool by which norms of tolerant communication are realized. And the principle of tolerance should be viewed as the basis of speech interaction. If the speaker happens to be a politician and tries to obey the cooperative principle, we still tend to look for hidden meanings that could be disguised by the speaker [7].

In any type of interview the assumption that that semantics and pragmatics are closely tangled with each other becomes very obvious. Pragmatic aspect is demonstrated by the hidden presence of the audience. The invisible presence of a reader or a listener - the "main addressee" - deprives the interlocutors of the opportunity to be sincere [1, p. 659]. Here comes forward the notion of tolerance. Continuing the idea of J. Searle and dividing the speech acts into direct and indirect ones, let's try to analyze the political interview with Hillary Clinton and see how tolerant she was in her answers. As one of the prominent figures Hillary Clinton has played a significant role in the political life of the United States since 2008. She actively supported Barack Obama win the presidential elections in 2008, her devotion as the Secretary of State was significant and noteworthy, in 2012, during the next elections, it was her husband's speech that became the cornerstone, a solid platform for Obama's reelection. The position of the Secretary of State considerably raised her rating among Americans; she enjoyed the support of the 
political elite and, at the same time, earned respect among the broad strata of the US population. In the presidential campaign of 2015, her popularity according to public opinion polls soared. And suddenly a scandal erupted in connection with sending from 2009 to 2013 service messages through her personal email. A statement was made that the use of a personal postal address for business purposes was a serious violation of the law. Basically, she was reproached for the fact that Hillary Clinton's personal address could be easily hacked by hackers. Democrats, of course, supported it, but, in general, a huge politically intolerant campaign started, she was ruthlessly and mercilessly criticized. If more recently she was on the top of glory, then within a moment her presidential plans dissolve in an outbreak of intolerant blows.

In a political interview, a pragmatic approach to communication is particularly prominent, implying agreement, the mutual dependence of the contextual environment and linguistic representation of the problem. Let's demonstrate it bringing some examples.

DAVID MUIR: Here we sit, five months into your campaign and there are some eyeopening poll numbers out there, and I'm sure you're aware of them, when it comes to how Americans see you. Our ABC poll, Gallup, Quinnipiac showing your favorability numbers taking a sharp dive.

In one poll, the lowest ever. And when voters were asked, "What is the first word that comes to mind when you think of Hillary Clinton?" Words like liar, dishonest, untrustworthy were at the top of the list. Does this tell you that your original explanation about the private server, that you did it to carry one phone out of convenience, that this didn't sit well with the American people?

Politicians often refer to direct or indirect speech acts. Direct or undeviating speech act use those politicians who present their views and intentions directly and openly. Meanwhile, some politicians prefer to hide their own point of view, the way their speech is uttered rarely expresses what, in fact, they mean. Pragmatic approaches to policy issues are realized through those linguistic units the use of which is to exert the necessary influence on the addressee. The addressee, in turn, tries to decipher what the politician has said, how clear and rational he is in his judgments, or how sincere he is. In a political interview, direct and indirect speech acts are realized simultaneously both by the politician and by the journalist.

In this interview, journalist David Muir starts a dialogue with Hillary Clinton, indicating the time frame. The attention of the addressee is directed to the period of Hillary Clinton's involvement in the election campaign. The time stretch suggests a positive, quite tolerant policy rating. Then some slightly intolerant notes make a way into the dialogue, a contrast is created by means of the word-combination opening poll numbers. The journalist openly talks about the results of the survey among the population, using a kind of colorful phrase. Then not wanting to offend Hillary Clinton, he uses an indirect speech act, citing the opinions of the respondents, and thus demonstrates intolerant approach of American people.

He calls her like a liar, dishonest, untrustworthy, words with striking, intolerant, negative connotations. So, to produce an effect on the addressee the journalist first spoke very tolerantly, and then completely intolerantly. By saying addressee we understand both Hillary Clinton and the audience. This interview is unprecedented as it conveys serious accusations against the candidate for the presidency of the United States. In an Anglo-American political culture, a politician uses a variety of indirect speech acts to remain tolerant, diplomatically obscure, vague, unclear, but this question has been put in the spotlight, and words such as a liar, dishonest, unreliable will undoubtedly force the politician to be frank and willing to try to rectify the situation in order to preserve the image before the electorate.

David Muir realized both direct and indirect speech acts, he represented outlined the situation that was developing at that moment, and then he called for an answer to Hillary Clinton. Intolerance was demonstrated in using indirect speech act and referring to the 
opinion of the electorate. It was a kind of verbal aggression that definitely should cause the politician feel awkward and uncomfortable. This is how Hillary Clinton responded to what was said.

HILLARY CLINTON: Well, David, obviously, I don't like hearing that. I am confident by the end of this campaign people will know they can trust me. And that I will be on their side and will fight for them and their families. But I do think I could have and should have done a better job answering questions earlier. I really didn't perhaps appreciate the need to do that. What I had done was allowed, it was above board. But in retrospect, certainly, as I look back at it now, even though it was allowed, I should've used two accounts. One for personal, one for work-related emails. That was a mistake. I'm sorry about that. I take responsibility. And I'm trying to be as transparent as I possibly can to not only release 55,000 pages of my emails, turn over my server. But I am looking forward, finally, to testifying before Congress. Something I've been asking for nearly a year.

Urging the audience to be tolerant, Hillary Clinton's replied through a combination of several speech acts. At the beginning of her response, she had the goal of expressing a psychological state of regret (Well, David, obviously, I do not like hearing that). Further, she commits herself to a whole series of obligations to the electorate (I am confident by the end of this campaign people will know they can trust me. And that I will be on their side and will fight for them and their families). Explicit grammatical structures I do not, I will, I am confident urge the audience to trust her. The speech act of regret is realized through sentences as I look back at it now, even though it was allowed, I should've used two accounts. That was a mistake. I'm sorry about that. I take responsibility.

The reaction of the audience to the received information might be interpreted either with tolerance or with complete intolerance. The listener tries to understand how sincere the politician is in his intentions. In order to revive the electorate's sense of trust in her, Hillary Clinton is trying to create an image of a sincere delusion. Sincerity in political discourse is one of the conditions for the success of tolerant communication; this is the shortest way to influence the audience. Violation of sincerity can completely destroy the reputation of the politician and breeds intolerance. Therefore, politicians deliberately enter into their speeches inclusions of sincerity in order afterward to manipulate the audience.

Let's see how Margaret Thatcher behaved when the journalist used a direct speech asking her about invading China.

Shaw: Lady Thatcher, the fact of the matter is you fought two wars, you came in and you took Hong Kong.

The parallel repetition of the pronoun you by the journalist, intensifies the idea and strengthens the reporter's intolerant discourse.

Her answer was: We did indeed take two wars, yes. We were, in fact, trading. There was, I'm afraid, some trade in drugs. None of us would defend that now. We have learnt a great deal in the 100-150 years and I can only wish that Mainland China had so much. If so we would never have had Tiananmen Square. We would never have had a cultural revolution.

The language behavior of Margaret Thatcher demonstrates a huge portion of tolerance. Hence, the selection or choice of those linguistic units that are based on social or cultural knowledge. By using the personal pronoun we and the emphatic construction did take, Margaret Thatcher expresses political unity with the history of Britain. The use of the personal pronoun "we" in this context is historically expanded, generalized. Margaret Thatcher does not want to deviate; she uses an emphatic verbal construction and then confirms the truth of her own statement: "yes." However, immediately in the following sentence she tries to evade, changing the communicative focus.

We were, in fact, trading. There was, I'm afraid, some trade in drugs.

The Prime Minister doesn't want to focus the attention of the audience on the history of 
the British Empire. The phrase I'm afraid expresses uncertainty and changes the modality of her tone. In linguistics, modals of a broader category are called hedges, and they include references to one's own subjective view. Hedges do not only single out the level of uncertainty, but can also be used to show tolerance, a polite unwillingness to criticize others.

Tolerant speech behavior in politics should be definitely characterized by respect for the partner in communication and to the value system he owns; by trust towards the partner in communication, by mutual penetration of interlocutors into the world of feelings and thoughts of each other, by mutual responsibility for the process and the result of communication.

\section{Bibliography}

1. Арутюнова Н. Д. Язык и мир человека. - М. : Языки русской культуры, 1999. - 896 с.

2. Грайс Г. П. Логика и речевое общение // Новое в зарубежной лингвистике. Лингвистическая прагматика. Вып. XVI. - М. : Прогресс, 1985.

3. Кифер Ф. О роли прагматики в лингвистическом описании // Новое в зарубежной лингвистике. Лингвистическая прагматика. Вып. XVI. - М. : Прогресс, 1985.

4. Красных В. В. Структура коммуникации в свете лингвокогнитивного подхода (коммуникативный акт, дискурс, текст): Дисс. ... д-ра филол. наук: 10.02.19. - М., 1999.
5. Остин Дж. Л. Слово как действие // Новое в зарубежной лингвистике. Теория речевых актов. Вып. XVII. - М. : Прогресс, 1986.

6. Репина Т. А. Французский язык в свете теории языкового общения. - СПб. : Изд-во Петерб. ун-та, 1992.

7. Серль Дж. Р. Косвенные речевые акты // Новое в зарубежной лингвистике. Теория речевых актов. Вып. XVII. - М. : Прогресс, 1986.

\section{Bibliography}

1. Arutjunova N. D. Jazyk i mir cheloveka. - M. : Jazyki russkoj kul'tury, 1999. - 896 s.

2. Grajs G. P. Logika i rechevoe obshhenie // Novoe v zarubezhnoj lingvistike. Lingvisticheskaja pragmatika. Vyp. HVI. - M. : Progress, 1985.

3. Kifer F. O roli pragmatiki v lingvisticheskom opisanii // Novoe $\mathrm{v}$ zarubezhnoj lingvistike. Lingvisticheskaja pragmatika. Vyp. HVI. - M. : Progress, 1985.

4. Krasnyh V. V. Struktura kommunikacii v svete lingvokognitivnogo podhoda (kommunikativnyj akt, diskurs, tekst): Diss. ... d-ra filol. nauk: 10.02.19. - M., 1999.

5. Ostin Dzh. L. Slovo kak dejstvie // Novoe v zarubezhnoj lingvistike. Teorija rechevyh aktov. Vyp. XVII. - M. : Progress, 1986.

6. Repina T. A. Francuzskij jazyk v svete teorii jazykovogo obshhenija. - SPb. : Izd-vo Peterb. un-ta, 1992.

7. Serl' Dzh. R. Kosvennye rechevye akty // Novoe v zarubezhnoj lingvistike. Teorija rechevyh aktov. Vyp. HVII. - M. : Progress, 1986.

(C) Simonyan A., 2017. 